\title{
Penerapan Pembelajaran Kontekstual untuk Meningkatkan Aspek Kognitif Siswa dengan Konsep Elektrolisis
}

\author{
Application of Contextual Learning to Improve the Cognitive Aspects of the \\ Students with the Electrolysis Concept
}

\author{
Wido Studianah \\ SMA Negeri 11 Bandung, Bandung, Jawa Barat, Indonesia \\ widostudianah@gmail.com
}

Naskah diterima tanggal 05/06/2019, direvisi akhir tanggal 26/06/2019, disetujui tanggal 31/07/2019

\begin{abstract}
Abstrak
Penelitian yang berjudul "Penerapan Pembelajaran Kontekstual untuk Meningkatkan Aspek Kognitif Siswa Kelas XII IPA Pada Konsep Elektrolisis” ini bertujuan untuk memperoleh gambaran tentang aspek kognitif siswa yang diterapkan melalui pembelajaran kontekstual pada materi sel elektrolisis. Selain itu dikaji pula partisipasi siswa selama pembelajaran. Untuk mengetahui peningkatan kemampuan kognitif siswa dilakukan penelitian dengan metode yang digunakan dalam penelitian adalah metode kuasi eksperimen desain pretest-postest. Subyek penelitian terdiri dari 46 orang siswa kelas XII IPA. Instrumen yang digunakan berupa lembar evaluasi (pretest dan postest), lembar kerja siswa (LKS), lembar pembelajaran, lembar observasi dan angket. Hasil penelitian menunjukkan bahwa penggunaan model pembelajaran kontekstual dapat meningkatkan kemampuan kognitif siswa dengan normalisasi gain 55,37\% (kategori cukup). Partisipasi siswa selama pembelajaran hampir setengahnya $(40,22 \%)$ siswa bertanya kepada guru atau kepada teman sekelompok, hampir setengahnya $(39,13 \%)$ siswa menjawab pertanyaan guru atau teman sekelompoknya dan sebagian besar $(90,94 \%)$ siswa aktif dalam kelompok. Hasil angket menunjukkan bahwa siswa merespon dengan baik pada pembelajaran kontekstual dengan menggunakan metode praktikum, Hal ini menunjukkan bahwa siswa cenderung lebih tertarik dengan pembelajaran yang mengangkat fakta-fakta yang mereka temukan dalam kehidupan sehari-hari.
\end{abstract}

Kata Kunci: Pembelajaran Kontekstual, Kognitif, Elektrolisis.

\section{Abstract}

The research aims to obtain an overview of the cognitive aspects of students that are applied through contextual learning on electrolysis cell material. In addition, student participation was also studied during learning. To find out the increase in cognitive abilities of students researched with the method used in the study was the quasi-experimental method of pretestposttest design. The research subjects consisted of 46 students of class XII IPA. The instruments used were evaluation sheets (pretest and posttest), student worksheets (LKS), learning sheets, observation sheets, and questionnaires. The results showed that the use of contextual learning models could improve the cognitive abilities of students with a normalized gain of $55.37 \%$ (sufficient category). Student participation during learning is almost half (40.22\%) students ask teachers or group friends, almost half (39.13\%) of students answer questions from teachers or group friends and most (90.94\%) students are active in groups. The questionnaire results show that students respond well to contextual learning, using practical methods. This shows that students tend to be more interested in learning that raises the facts they find in daily life.

Keywords: Contextual Learning, Cognitive, Electrolysis. 


\section{PENDAHULUAN}

Pendidikan di Indonesia sejauh ini masih didominasi oleh pandangan pembelajaran konvensional yang mana pengetahuan sebagai kerangka fakta-fakta yang harus dihapal. Kelas masih terfokus kepada guru sebagai sumber pengetahuan, kemudian ceramah menjadi pilihan utama strategi belajar. Guru kadang-kadang tidak memiliki cukup waktu untuk melakukan percobaan di kelas, mengingat bahan ajar yang akan disampaikan pada waktu tertentu telah ditargetkan dalam kurikulum. Interaksi yang terjadi dalam pembelajaran hanya satu arah dan menekankan pada aspek kognitif siswa saja, sedangkan aspek apektif dan aspek psikomotor siswa kurang diperhatikan. Siswa " hanya mengetahui " dan tidak" mengalami " apa yang dipelajarinya. Untuk itu diperlukan strategi belajar yang "baru" yang lebih memberdayakan siswa student centered. Sebuah strategi belajar yang tidak mengharuskan siswa menghapal fakta-fakta, melainkan sebuah strategi yang mendorong siswa mengkontruksi pengetahuan di benak mereka sendiri.

Pembelajaran Konvensional yang berorientasi pada penguasaan materi terbukti berhasil dalam kompetisi 'mengingat' jangka pendek, tetapi gagal dalam membekali siswa memecahkan persoalan dalam kehudupan jangka panjang, dan hal itulah yang terjadi di sekolah-sekolah kita (Rohman, 2009). Untuk dapat bertahan dalam persaingan hidup yang semakin kompetitif, siswa harus memiliki "life skill" yang merupakan modal untuk hidup jangka panjang.

Tujuan pembelajaran kimia di SMA terintegrasi pada tujuan pembelajaran IPA, diantaranya memahami konsep konsep IPA dan saling keterkaitannya serta memberikan bekal pengetahuan dasar untuk melanjutkan kejenjang pendidikan yang lebih tinggi dan dapat menerapkannya didalam kehidupan sehari hari (Rustaman, 1996). Dalam usaha pencapaian tujuan tersebut diharapkan pembelajaran kimia lebih ditekankan pada cara agar siswa menguasai konsep konsep dan keterkaitannya satu sama lain.

Ad Rooijakkers (1999) mengemukakan bahwa suatu bahan akan berarti kalau bahan yang diajarkan mempunyai kaitan dengan pengetahuan yang ada dalam benak murid (pengetahuan pendahuluan). Keberhasilan mempelajari sesuatu tergantung kepada ada tidaknya kemampuan yang lebih sederhana yang telah dipelajari sebelumnya. Hal ini menunjukkan bahwa konsep-konsep atau prinsip-prinsip yang telah dipelajari hendaknya relevan dengan konsep-konsep atau prinsip-prinsip yang akan diajarkan.

Pembelajaran Berbasis Kontekstual (Contextual Teaching and Learning, CTL) merupakan strategi belajar yang membantu guru mengkaitkan antara materi yang diajarkan dengan situasi dunia nyata siswa dan mendorong siswa menghubungkan antara pengetahuan yang dimilikinya, dengan penerapan dalam kehidupan mereka sebagai anggota keluarga dan masyarakat (Echolas \& Shadily, 1999). Dengan pemikiran tersebut hasil pembelajaran lebih bermakna bagi siswa (Sanjaya, 2005; Zayadi \& Majid, 2008). Proses pembelajaran berlangsung alamiah dalam bentuk kegiatan siswa bekerja dan mengalami, bukan transper pengetahuan dari guru kepada siswa. Strategi atau proses pembelajaran lebih dipentingkan dari pada hasil belajar (Rohman, 2009; Sagala, 2006; Taniredja, 2013).

Digulirkannya Pembelajaran Berbasis Kontekstual, seiring dengan implementasi Kurikulum 2013 (KURTILAS) di sekolah dapat mempermudah dalam merencanakan dan melaksanakan pembelajaran kimia. Kurtilas memuat penekanan pada kompetensi (kemampuan) siswa, yang memerlukan adanya suatu pembelajaran yang menerapkan dan mendukung kurikulum tersebut, yaitu pembelajaran yang memuat pandangan: (1) konstruktivisme, (2) siswa belajar melalui pengalamannya atau belajar bermakna (3) siswa meningkatkan sendiri kompetensinya, serta (4) siswa menemukan dan membangun konsepnya sendiri secara alamiah atau dibuat alami. Pembelajaran yang memuat empat pandangan diatas adalah Pembelajaran Berbasis Kontekstual. Apakah Pembelajaran Berbasis Kontekstual berhasil meningkatkan penguasaan konsep reaksi sel elektrolisis 
pada proses penyepuhan siswa SMA kelas XII IPA. Berdasarkan kenyataan tersebut, penulis tertarik untuk melakukan penelitian mengenai model pembelajaran berbasis kontekstual dalam meningkatkan kemampuan kognitif siswa pada materi elektrolisis.

\section{METODE PENELITIAN}

Metoda penelitian yang digunakan yaitu metoda eksperimen dengan One Group pretest-postest design. Desain observasi ini dilakukan sebanyak dua kali yaitu sebelum eksperimen dan sesudah eksperimen. Observasi yang dilakukan sebelum eksperimen disebut dengan pretest dan observasi sesudah eksperimen disebut postest. Perbedaan antara pretest dan postest diasumsikan merupakan efek dari treatment atau eksperimen. Dalam penelitian ini peningkatkan kemampuan diukur dengan angka normalitas gain dimana selisih antara nilai pretes dan postes dibandingkan dengan selisih antara nilai maksimum dengan nilai pretes.
Subjek dalam penelitian ini yaitu siswa SMA kelas XII IPA yang sedang mempelajari sub pokok bahasan aplikasi elektrolisis yang berjumlah 46 siswa. Siswa yang menjadi subjek penelitian ini dibagi menjadi 8 kelompok pada saat pembelajaran. Pada saat pengolahan data, siswa dibagi menjadi tiga kategori, kategori tinggi, kategori sedang dan kategori rendah. Pengelompokkan tersebut berdasarkan perolehan nilai ulangan harian terakhir mata pelajaran kimia.

Instrumen yang digunakan dalam penelitian ini diantaranya : (1) lembar kerja siswa, (2) tes objektif, (3) lembar observasi, (4) angket atau kuisioner. Sedangkan analisis data dan uji instrumen dilakukan sebagai berikut :

1. Validitas Butir Soal

Validitas instrumen penelitian dengan pola pilihan ganda, menggunakan uji product moment (Arikunto, 2002) dengan rumus sebagai berikut :

Keterangan :

$$
\mathbf{r}_{\mathrm{xy}}=\frac{N \sum X Y-\left(\sum X\right)\left(\sum Y\right)}{\left.\sqrt{\left\{N \sum X^{2}\right.}-\left(\sum X\right)^{2}\right\}\left(N \sum Y^{2}-\left(\sum Y\right)^{2}\right\}}
$$

$\mathrm{r}_{\mathrm{xy}} \quad$ : Validitas suatu butir soal

$\mathrm{N}:$ Jumlah peserta tes

$\mathrm{X}$ : Nilai satu butir soal

Y : Nilai total

Kriteria acuan untuk validitas butir soal adalah sebagai berikut:

Tabel 1. Derajat validitas soal

\begin{tabular}{cc}
\hline Rentang & Keterangan \\
\hline $0,80-1,00$ & Sangat Tinggi \\
\hline $0,60-0,79$ & Tinggi \\
\hline $0,40-0,59$ & Cukup \\
\hline $0,20-0,39$ & Rendah \\
\hline $0,00-0,19$ & Sangat Rendah \\
\hline
\end{tabular}

(Arikunto, 2002)

Dari hasil analisis uji validitas tabel 1 dan tabel 2 menunjukkan bahwa validitas dari soal tersebut secara umum termasuk dalam kategori cukup sampai tinggi, sehingga layak untuk dijadikan instrumen penelitian. Dari perhitungan 15 butir soal yang diujicobakan diperoleh hasil sebagai berikut : 
Tabel 2. Rekapitulasi hasil perhitungan Validitas

\begin{tabular}{lclr}
\hline $\begin{array}{c}\text { Interpretasi Daya } \\
\text { Pembeda }\end{array}$ & $\sum$ Soal & Nomor Soal & \multicolumn{1}{c}{$\%$} \\
\hline Sangat Tinggi & 0 & & 0 \\
\hline Tinggi & 0 & & 0 \\
\hline Cukup & 11 & $1,2,4,7,9,10,11,12,13,14$, dan 15 & 73,33 \\
\hline Rendah & 0 & & 0 \\
\hline Sangat Rendah & 4 & $3,5,6$. dan 8 & 26,67 \\
\hline
\end{tabular}

\section{Realibilitas Tes}

Firman (2003) mengungkapkan bahwa relibilitas adalah ukuran sejauh mana suatu alat ukur memberikan gambaran yang benar-benar dapat dipercaya tentang kemampuan seseorang (bukan palsu). Jika alat ukur mempunyai realibilitas yang tinggi maka pengukuran yang dilakukan berulang-ulang terhadap subjek yang sama pada kondisi yang sama akan menghasilkan informasi yang sama atau mendekati sama. Pengujian realiabilitas pada soal pilihan ganda menggunakan rumus: K-R 20 (Arikunto, 2002).

$$
r_{11}=\left(\frac{K}{K-1}\right)\left(\frac{V t-\sum p q}{V t}\right)
$$

Keterangan

$\mathrm{k} \quad=$ jumlah soal

$\mathrm{p} \quad=$ proporsi respon betul pada suatu soal

$\mathrm{q}=$ proporsi respon salah pada suatu soal

$\mathrm{Vt}=$ Variansi skor-skor tes

$r_{11} \quad=$ realibilitas instrumen

Adapun kriteria acuan untuk antara siswa yang menguasai dengan siswa realibilitas tes seperti pada tabel 1 .

3. Daya Pembeda

Instrumen yang baik dapat membedakan yang tidak menguasai. Untuk ini instrumen harus memiliki daya pembeda (Arikunto, 2002) dengan rumus sebagai berikut :

$$
\mathrm{DP}=\frac{B a}{J a}-\frac{B b}{J b}
$$

Keterangan :

DP : daya pembeda

$\mathrm{Ba}$ : banyaknya peserta kelompok atas yang menjawab benar

$\mathrm{Bb}$ : banyaknya peserta kelompok yang menjawab benar

Ja : banyaknya peserta kelompok atas

$\mathrm{Jb}$ : banyaknya peserta kelompok bawah

Kriteria acuan untuk daya pembeda yang digunakan seperti pada tabel 1. Berdasarkan hasil analisis daya pembeda pada tabel 3, maka soal yang layak digunakan dalam tes sebanyak $\mathrm{X}$ soal dapat dilihat pada tabel berikut:

Tabel 3. Rekapitulasi hasil perhitungan Daya Pembeda

\begin{tabular}{lccr}
\hline \multicolumn{1}{c}{ Interpretasi Daya Pembeda } & $\sum$ Soal & Nomor Soal & \multicolumn{1}{c}{$\%$} \\
\hline Sangat baik & 2 & 7,10 & 13,33 \\
\hline Baik & 9 & $1,2,7,10,11,12,13,14,15$ & 60,00 \\
\hline Cukup, kemungkinan harus direvisi & 0 & - & 0 \\
\hline Jelek, sebaiknya dibuang & 4 & $3,5,6$, dan 8 & 26,67 \\
\hline Sangat jelek, sebaiknya dibuang & 0 & - & 0 \\
\hline
\end{tabular}


4. Tingkat Kesukaran

Tingkat Kesukaran satu batir soal pilihan ganda, dapat diuji melalui uji tingkat kesukaran (Karno, 1996: 11) dengan humus sebagai berikut:

$$
\mathrm{TK}=\frac{B a+B b}{J a+J b}
$$

Keterangan :

TK : tingkat kesukaran

$\mathrm{Ba}$ : banyaknya peserta kelompok atas yang menjawab benar

$\mathrm{Bb}$ : banyaknya peserta kelompok bawah yang menjawab benar

Ja : banyaknya peserta kelompok atas

$\mathrm{Jb} \quad$ : banyaknya peserta kelompok bawah

Kriteria acuan tingkat kesukaran yang digunakan seperti pada tabel 1. Dari hasil uji coba soal (tabel 4) diperoleh berbagai tingkat kesukaran dari tiap butir soal. Adapun rekapitulasi tingkat kesukaran dari 15 soal yang diujicobakan adalah dapat dilihat pada tabel berikut ini:

Tabel 4. Rekapitulasi hasil perhitungan Tingkat Kesukaran

\begin{tabular}{lccr}
\multicolumn{1}{c}{ Interpretasi Daya Pembeda } & S Soal & Nomor soal & \% \\
\hline Sangat mudah & - & - & - \\
\hline Mudah & 4 & $3,5,6$, dan 8 & 26,67 \\
\hline Cukup, kemungkinan harus direvisi & 11 & $1,2,4,7,9,10,11,12,13,14$ dan 15 & 73,33 \\
\hline Sukar & - & - & - \\
\hline Sangat sukar & - & - & - \\
\hline
\end{tabular}

Teknik pengumpulan data dalam penelitian dapat dilihat pada tabel berikut ini.

Tabel 5. Teknik Pengumpulan data

\begin{tabular}{|c|c|c|}
\hline No & Jenis Data & Instrumen \\
\hline 1 & $\begin{array}{l}\text { Penguasaan konsep siswa dalam subkonsep dasar dan } \\
\text { tujuan proses penyepuhan }\end{array}$ & $\begin{array}{l}\text { Soal Pretes-postes dan Lembar } \\
\text { Kerja Siswa (LKS) }\end{array}$ \\
\hline 2 & $\begin{array}{l}\text { Aktivitas belajar siswa selama melakukan model } \\
\text { pembelajaran berbasis kontekstual }\end{array}$ & Lembar observasi (daftar cek) \\
\hline 3 & $\begin{array}{l}\text { Tanggapan siswa terhadap model pembelajaran } \\
\text { berbasis kontekstual pada sub konsep dasar dan tujuan } \\
\text { proses penyepuhan }\end{array}$ & Angket \\
\hline
\end{tabular}

Pengujian data secara statistik, dilakukan pada tarap kepercayaan $\underline{\alpha}=$ 0,05 . Rata-rata pretes dan postes ditentukan kemudian dihitung selisih antara nilai pretes dan postes sehingga diperoleh gain, kemudian dilakukan uji normalitas, homogenitas dan hipotesis terhadap data yang telah diperoleh (Cohen \& Fowler, 1990: 77), sehingga data menjadi lebih bermakna. Penjelasan lebih lanjut mengenai pengolahan data (tabel 5) penguasaan koonsep akan diuraikan sebagai berikut :

a. Memberi skor mentah sebagai nilai tes penguasaan konsep baik pretest maupun postest dengan rentang nilai $0-100$.

b. Mencari gain nilai penguasaan konsep.

c. Melakukan uji prasyarat yang terdiri dari uiji normalitas dan uji homogenitas, hal ini diperlukan untuk menetapkan apakah pengujian hipotesis dilakukan secara parametrik atau non parametrik ( sudjana,1996: 293 ).

\section{HASIL DAN PEMBAHASAN}

1. Peningkatan Kemampuan Kognitif Seluruh Siswa

Peningkatan kemampuan kognitif siswa diukur dengan membandingkan data 
pretes dan postes siswa. Secara kuantitatif, peningkatan kemampuan kognitif siswa ditunjukkan dengan nilai normalisasi gain.
Berikut ini merupakan Tabel hasil pengolahan data nilai rata-rata pretes dan postes untuk masing-masing kategori kelompok.

Tabel 6. Rata-rata Pretes, Postes dan Normalisasi Gain (\%) Siswa Secara Keseluruhan pada setiap Kategori

\begin{tabular}{ccccc}
\hline Parameter & \multirow{2}{*}{ Keseluruhan } & \multicolumn{3}{c}{ Kategori } \\
\cline { 3 - 5 } & & Tinggi & Sedang & Rendah \\
\cline { 2 - 5 } Jumlah Siswa & 40 & 10 & 20 & 10 \\
Pretes & 52,41 & 66,10 & 53,08 & 37,26 \\
Nilai Rata-rata & 12,70 & 7,12 & 8,23 & 7,61 \\
Simpangan Baku & 16,14 & 50,7 & 68,66 & 57,88 \\
Variansi & 27,27 & 54,55 & 36,36 & 27,27 \\
Nilai Minimum & 72,73 & 72,73 & 63,64 & 45,6 \\
Nilai Maksimum & 77,89 & 92,56 & 78,03 & 62,82 \\
Postes & 11,91 & 3,68 & 5,31 & 8,55 \\
Nilai Rata-rata & 14,18 & 13,54 & 28,15 & 73,03 \\
Simpangan Baku & 54,55 & 90,91 & 72,73 & 45,6 \\
Variansi & 100 & 100 & 90,91 & 72,73 \\
Nilai Minimum & 55,37 & 77,42 & 52,52 & 39,53 \\
Nilai Maksimum & & & &
\end{tabular}

Berdasarkan tabel 6, diperoleh nilai rata-rata pretes sebesar 52,41\% dari nilai rata-rata ideal $100 \%$ dan nilai rata-rata postes sebesar $77,89 \%$ dari nilai rata-rata ideal $100 \%$. Dengan perbandingan nilai rata-rata pretes dan postes di atas, terjadi peningkatan kemampuan kognitif yang diukur dengan normalisasi gain, yaitu 55,37\%.

2. Peningkatan Kemampuan Kognitif Siswa untuk setiap Kategori

Berdasarkan data hasil pretes dan postes untuk setiap kategori (gambar 1), tampak bahwa rata-rata nilai pretes dan nilai postes tertinggi diperoleh kelompok tinggi. Pada siswa kategori tinggi, diperoleh nilai rata-rata pretes sebesar $66,10 \%$ dan nilai rata-rata postes $92,56 \%$. Ini menggambarkan bahwa sebelum pembelajaran rata-rata kemampuan siswa kategori tinggi tergolong baik, sedangkan setelah pembelajaran kemampuan siswa kategori tinggi sangat baik. Pada kategori ini normalitas gain yang diperoleh $77,42 \%$.

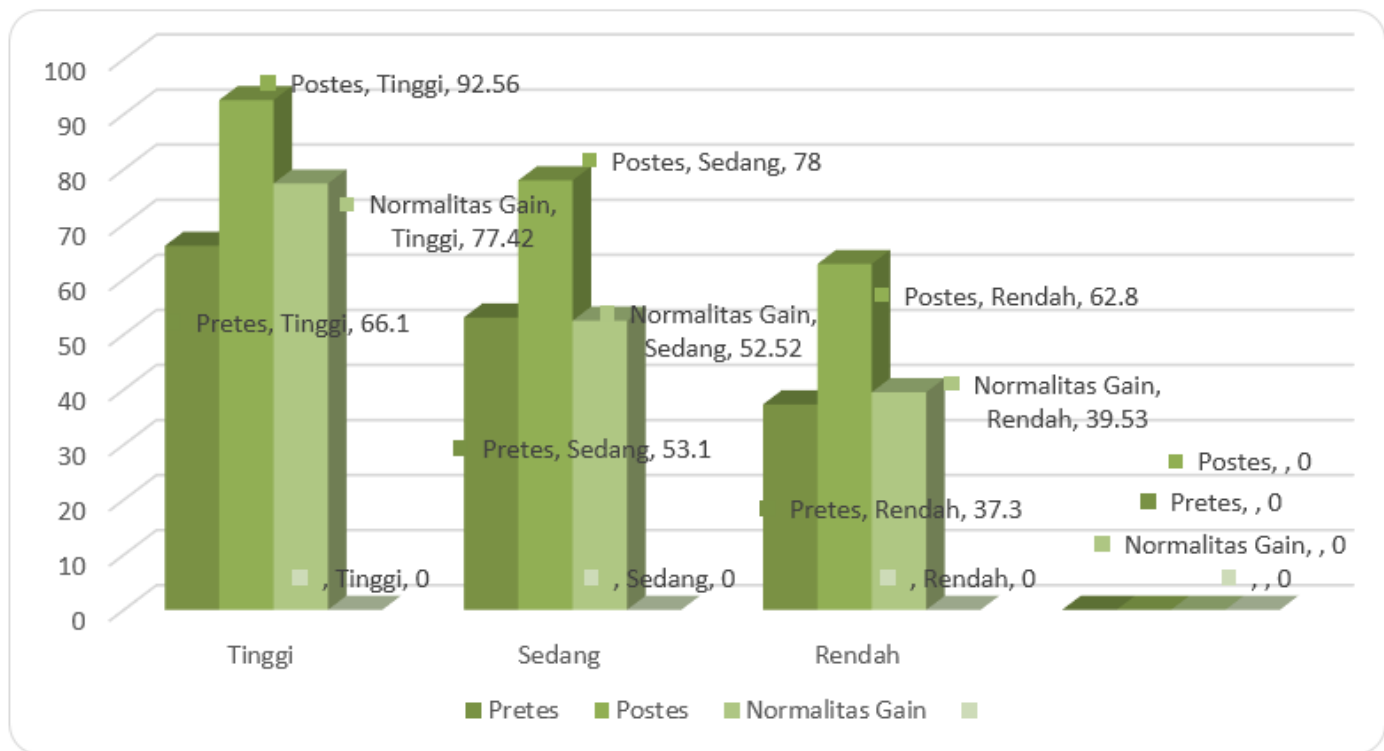

Gambar 1. Nilai Rata-rata Pretes, Postes dan Normalisasi Gain Siswa pada setiap Kategori Kelompok 
Pada kategori sedang, nilai rata-rata pretes sebesar $53,08 \%$ dan nilai rata-rata postes sebesar $78,02 \%$. Ini berarti sebelum pembelajaran kemampuan rata-rata siswa kelompok sedang tergolong cukup dan terjadi peningkatan sehingga kemampuan siswa kategori sedang tergolong baik. Peningkatan penguasaan konsep siswa kategori sedang secara kuantitatif ditunjukkan oleh nilai normalisasi gain sebesar 52,52\%.

Untuk kategori rendah, diperoleh nilai rata-rata pretes sebesar $37,26 \%$ dan nilai rata-rata postes sebesar $62,82 \%$. Ini berarti sebelum pembelajaran kemampuan rata-rata siswa kelompok rendah tergolong kurang. Setelah pembelajaran kemampuan rata-rata siswa kelompok rendah tergolong baik dan terjadi peningkatan kemampuan siswa yang ditunjukkan oleh normalisasi gain sebesar $39,53 \%$. Berkut ini ditampilkan grafik peningkatan kemampuan kognitif siswa pada setiap kategori.

Selain soal kemampuan kognitif yang berupa soal objektif, data penunjang lainnya berupa Lembar Kerja Siswa ( LKS ) yang diberikan kepada siswa secara berkelompok untuk mengarahkan siswa ketika pembelajaran berlangsung. Keberhasilan suatu proses pembelajaran dipengaruhi oleh faktor internal maupun eksternal. Salah satu faktor internal yang mempengaruhi hasil belajar siswa adalah media yang digunakan dalam proses pembelajaran. Dalam hal ini LKS sangat membantu kelancaran proses pembelajaran bahkan dapat mempengaruhi peningkatan kemampuan penguasaan konsep proses penyepuhan.

Pengolahan data pada LKS pada gambar 2 menunjukkan bahwa rata-rata nilai LKS untuk kelompok tinggi $(89,45)$ tergolong kategori sangat tinggi, dan ratarata nilai LKS pada kelompok sedang $(78,00)$ tergolong kategori tinggi, sedangkan ratarata nilai LKS kelompok rendah $(70,91)$ tergolong kategori tinggi. Berdasarkan hasil angket siswa menunjukkan bahwa sebagian besar siswa $(93,48 \%)$ berpendapat LKS yang digunakan dalam pembelajaran kontekstual dapat membantu siswa memahami materi proses penyepuhan. Berikut ini ditampilkan gambar nilai rata-rata lembar kerja siswa (LKS).

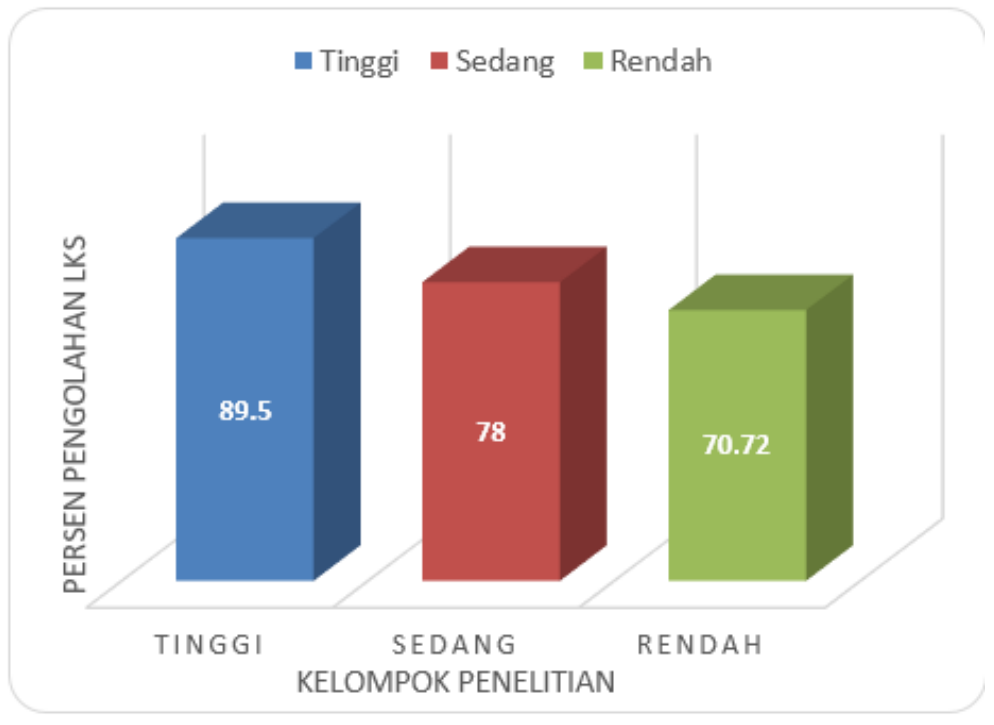

Gambar 2. Hasil Penilaian Lembar Kerja Siswa LKS

3. Hasil Data Aktivitas Belajar Siswa

Tabel 7. Persentase Aktivitas Siswa dalam Pembelajaran

\begin{tabular}{ccc}
\hline \multicolumn{3}{c}{ Persentase jumlah siswa } \\
\hline Bertanya & $\begin{array}{c}\text { Menjawab } \\
\text { Pertanyaan }\end{array}$ & Group Work \\
\hline 40,22 & 39,13 & 90,94 \\
\hline
\end{tabular}


Berdasarkan tabel 7 hampir setengahnya $(40,22 \%)$ Siswa aktif bertanya, baik pertanyaan terbuka maupun tertutup. Begitu pula pada kegiatan menjawab pertanyaan hampir setengahnya $(39,13 \%)$ siswa terlibat dalam kegiatan menjawab pertanyaan dan sebagian besar $(90,94 \%)$ siswa aktif dalam kelompok. Berikut ini ditampilkan gambar persentase aktivitas siswa dalam pembelajaran.

4. Hasil Data Tanggapan Siswa terhadap

Model Pembelajaran Kontekstual

Berdasarkan hasil angket yang disebarkan dan wawancara tentang tanggapan siswa terhadap model pembelajaran kontekstual maka dapat di simpulkan beberapa hal sebagai berikut :

a. Pembelajaran Kontekstual yang diterapkan pada sel elektrolisis pada proses penyepuhan sangat baik dan dapat membuat anak dapat berpikir kritis.

b. Pembelajaran Kontekstual dapat meningkatkan motivasi siswa dan dapat menghilangkan rasa jenuh siswa.

c. Model Pembelajaran Kontekstual dapat berhubungan langsung dalam kehidupan sehari-hari, sehingga materi yang sedang dipelajari akan sesuai dengan fakta.

d. Guru menyarankan dalam pembelajaran kontekstual guru harus lebih kreatif dan inovatif, karena dengan pembelajaran kontekstual siswa akan banyak mencari dan menemukan konsep sendiri.

\section{KESIMPULAN}

Berdasarkan hasil temuan dan pembahasan penelitian yang telah dilakukan maka dapat diambil kesimpulan bahwa kemampuan kognitif siswa dan aktivitas siswa selama pembelajaran berlangsung dengan mengunakan pendekatan kontekstual denagan menggunakan metode praktikum termasuk kategori kemampuan baik. Adapun kemampuan kognitif dan aktivitas siswa adalah sebagai berikut: 1) Kemampuan kognitif siswa pada proses penyepuhan tergolong baik, dan mengalami peningkatan signifikan dari kemampuan awal dan akhir (meningkat 55,37\%); 2) Selama pembelajaran siswa menunjukkan partisipasi yang baik dalam kegiatan bertanya, menjawab pertanyaan dan dalam kerjakelompok. Selama pembelajaran, hampir setengahnya (40,22\%) dari siswa aktif memberikan pertanyaan baik pertanyaan terbuka atau tertutup kepada guru maupun teman sekelompoknya atau dari kelompok lain. Aktivitas siswa di dalam menjawab pertanyaan dari guru ataupun dari temannya termasuk kategori cukup, sebagian besar siswa aktif $(90,94 \%)$ dalam kelompok; 3) Sebagian besar (69,56\%) siswa berpendapat dengan belajar kelompok pada waktu pembelajaran berlangsung dapat membantu siswa memahami materi; 4) Sebagian besar $(86,96 \%)$ siswa berpendapat bahwa pembelajaran kontekstual pada proses penyepuhan sangat membantu untuk bisa mencari dan menemukan konsep sendiri.

Selanjutnya berdasarkan hasil penelitian dan temuan dilapangan, peneliti ingin mengemukakan beberapa saran sebagai berikut; 1) Hasil penelitian menunjukkan bahwa pembelajaran kontekstual dapat meningkatkan hasil kognitif siswa, oleh karena itu model ini dapat menjadi alternatif model pembelajaran untuk diterapkan pada bahan kajian lain agar pembelajaran dapat bermakna; 2) Hasil penelitian ini menunjukkan bahwa model pembelajaran ini prosfektif untuk digunakan,meskipun penelitan ini baru dilakukan secara terbatas. Perlu dilakukan penelitian subjek penelitian yang lebih luas dan penggunaan instrument yang lebih banyak dalam peningkatan kemampuan kognitif.

\section{DAFTAR PUSTAKA}

Arikunto, Suharsimi. (2002). Prosedur Penelitian suatu Pendekatan Praktek (edisi V). Jakarta.: Rineka Cipta.

Firman, H. (2003). Penilaian Hasil Belajar Dalam Pengajaran Kimia. Bandung: Jurusan Kimia FPMIPA IKIP Bandung.

Rustaman, N. Y. (1996). Common Textbook (Edisi Revisi) Strategi Belajar Mengajar Biologi. Bandung: Jurusan Pendidikan Biologi FPMIPA Universitas Pendidikan Indonesia.

Rohman, A. (2009). Memahami Pendidikan dan Ilmu Pendidikan. Yogyakarta: LaksBang Mediatama. 
Rustaman, N. Y. (2007). Kemampuan Dasar Bekerja Ilmiah dalam Pendidikan Sains dan Asesmennya. Bandung: The First International Seminar of Science Education on Education Facing Against the Challenges of the 21 st Century.

Ad Rooijakkers. (1999). Mengajar dengan Sukses Petunjuk untuk Merencanakan dan Menyampaikan Pengajaran. Jakarta: PT. Grafindo.

Sanjaya, W. (2005). Pembelajaran dalam Implementasi Kurikulum Berbasis Kompetensi. Jakarta: Kencana.

Zayadi A., \& Majid, A. (2004). Pembelajaran Pendidikan Agama Islam (PAI) Berdasarkan Pendekatan Kontekstual. Jakarta: Rajawali Press.

Sagala, S, (2006). Konsep dan Makna Pembelajaran, Bandung: Alfabeta.

Echolas, J. M., \& Shadily, H. (1999). Kamus Inggris Indonesia. Jakarta: Gramedia.

Taniredja, T. (2013). Model-Model Pembelajaran Inovatif dan Efektif. Bandung: Alfabeta. 